Article

\title{
Optimized Photodynamic Therapy with Multifunctional Cobalt Magnetic Nanoparticles
}

\author{
Kyong-Hoon Choi ${ }^{1}$, Ki Chang Nam ${ }^{2}$, Un-Ho Kim ${ }^{3}$, Guangsup Cho ${ }^{1}$, Jin-Seung Jung ${ }^{3, *}$ and \\ Bong Joo Park 1,* \\ 1 Department of Electrical \& Biological Physics, Kwangwoon University, Nowon-gu, Seoul 139-701, Korea; \\ solidchem@hanmail.net (K.-H.C.); gscho@kw.ac.kr (G.C.) \\ 2 Department of Medical Engineering, Dongguk University College of Medicine, Gyeonggi-do 10326, Korea; \\ kichang.nam@gmail.com \\ 3 Department of Chemistry, Gangneung-Wonju National University, Gangneung 210-702, Korea; \\ rladydanr06@naver.com \\ * Correspondence: jjscm@gwnu.ac.kr (J.-S.J.); parkbj@kw.ac.kr (B.J.P.); \\ Tel.: +82-33-640-2305 (J.-S.J.); +82-2-940-8629 (B.J.P.)
}

Received: 2 May 2017; Accepted: 7 June 2017; Published: 10 June 2017

\begin{abstract}
Photodynamic therapy (PDT) has been adopted as a minimally invasive approach for the localized treatment of superficial tumors, representing an improvement in the care of cancer patients. To improve the efficacy of PDT, it is important to first select an optimized nanocarrier and determine the influence of light parameters on the photosensitizing agent. In particular, much more knowledge concerning the importance of fluence and exposure time is required to gain a better understanding of the photodynamic efficacy. In the present study, we synthesized novel folic acid-(FA) and hematoporphyrin (HP)-conjugated multifunctional magnetic nanoparticles $\left(\mathrm{CoFe}_{2} \mathrm{O}_{4}\right.$-HPs-FAs), which were characterized as effective anticancer reagents for PDT, and evaluated the influence of incubation time and light exposure time on the photodynamic anticancer activities of $\mathrm{CoFe}_{2} \mathrm{O}_{4}$-HPs-FAs in prostate cancer cells (PC-3 cells). The results indicated that the same fluence at different exposure times resulted in changes in the anticancer activities on PC-3 cells as well as in reactive oxygen species formation. In addition, an increase of the fluence showed an improvement for cell photo-inactivation. Therefore, we have established optimized conditions for new multifunctional magnetic nanoparticles with direct application for improving PDT for cancer patients.
\end{abstract}

Keywords: photodynamic therapy; optimized nano-carrier; multifunctional magnetic nanoparticle; fluence; anticancer activity; prostate cancer cell

\section{Introduction}

Over the last few decades, photosensitizer (PS)-mediated photodynamic therapy (PDT) has been introduced as a possible alternative non-invasive localized therapeutic modality for treating cancer as well as cardiovascular, ophthalmic, dermatological, and dental diseases [1-7]. PDT is a two-step procedure that involves the administration of a photosensitizing agent [8], followed by activation of the drug with non-thermal light of a specific wavelength [9]. In particular, this photodynamic process rapidly generates reactive oxygen species (ROS) including peroxides, hydroxyl radicals, superoxide ions, and singlet oxygen, with the latter implicated as the major causative agent of cellular damage in the photodynamic process [10]. However, the results of recent clinical and preclinical studies of PDT indicate that this process still suffers from disadvantages such as the wavelength-dependent tissue penetration depth of the light; inefficient delivery of PS to the target area; loss of PDT efficacy owing to PS aggregation, degradation, or reduction; and toxicity of the PS [11-13]. 
Several approaches have been proposed to enhance the efficacy of PDT. In some cases, PDT efficacy was found to be significantly improved when nanoparticles were applied as PS carriers, suggesting that the use of nanoparticles can help to overcome the aforementioned limitations [14-16]. Among the various nanoparticles available, such as liposomal vesicles, quantum dots, nanotubes, and gold nanoparticles, the latter have attracted substantial attention because of their chemical inertness, excellent optical properties, and minimal biological toxicity $[17,18]$. Recently, new synergistic treatment modalities that combine PDT with hyperthermia by using Au nanocomposites have shown the potential to overcome the current limitations of PDT and enhance anticancer efficacy [19-21]. However, the Au nanocomposites must overcome many disadvantages, including higher cost, low conjugation efficiency on the surface of particles, and lack of bio-imaging capability. To improve PDT efficacy, it is also important to understand the photophysical and photochemical properties of as-prepared photosensitizing agents. In particular, the illumination parameters might play an important role in determining PDT efficacy.

Herein, we report the development of new multifunctional magnetic nanoparticles conjugated with hematoporphyrin (HP) and folic acid (FA) ( $\mathrm{CoFe}_{2} \mathrm{O}_{4}$-HPs-FAs) for use as potential PDT agents, which were tested by targeting prostate cancer PC-3 cells with FA. The biocompatibility and photodynamic anticancer activity of the $\mathrm{CoFe}_{2} \mathrm{O}_{4}$-HPs-FAs were evaluated in vitro. In addition, we evaluated the effect of variations in the fluence and exposure time on the outcome of the photodynamic anticancer activity of $\mathrm{CoFe}_{2} \mathrm{O}_{4}$-HPs-FAs in PC-3 cells to corroborate the importance of optimizing the irradiation parameters.

\section{Results and Discussion}

\subsection{Characteristics of Multifunctional $\mathrm{CoFe}_{2} \mathrm{O}_{4}-\mathrm{HPs}$-Fas}

As illustrated in Scheme 1, novel multifunctional magnetic nanoparticles $\left(\mathrm{CoFe}_{2} \mathrm{O}_{4}\right.$-HPs-FAs) were prepared by simple surface modification of magnetic nanoparticles with a photosensitizer, $\mathrm{HP}$, and a targeting molecule, FA. First, two carboxyl terminal groups of HP are chemically bonded to metal cations on the surface of the $\mathrm{CoFe}_{2} \mathrm{O}_{4}$ nanoparticles via esterification reaction. Similarly, the FA molecules were introduced to the surface of the $\mathrm{CoFe}_{2} \mathrm{O}_{4}$ nanoparticles to improve the targeting ability.

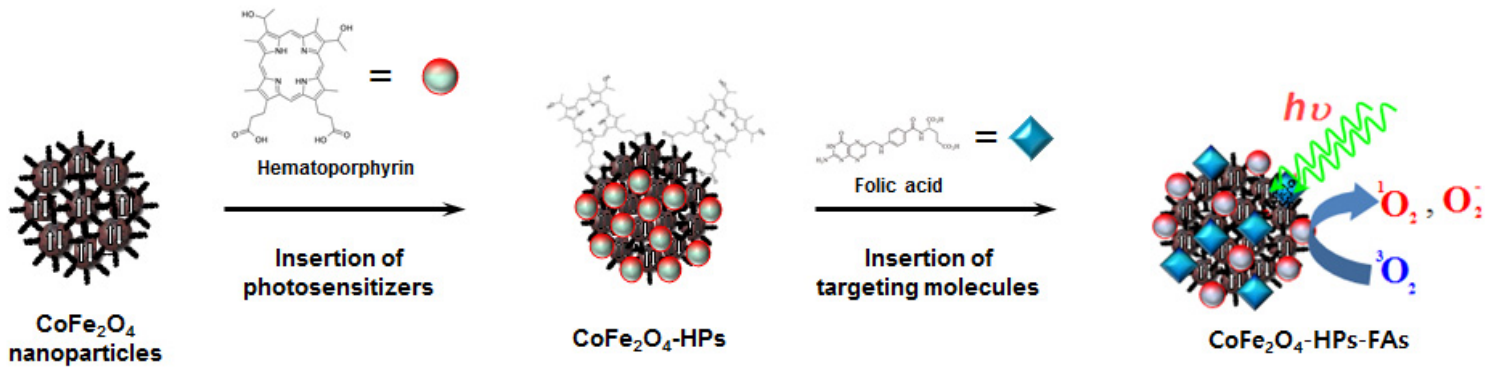

Scheme 1. Fabrication procedure for the multifunctional magnetic nanoparticles.

The morphology and particle size of the as-prepared $\mathrm{CoFe}_{2} \mathrm{O}_{4}$ nanoparticles were characterized by transmission electron microscopy (TEM; JEOL, JEM-2100F) and scanning electron microscopy (SEM; Hitachi, SU-70), as shown in Figure 1a,b, respectively. The SEM and TEM images showed that these nanoparticles composed of irregular nanograins are spherical and have a diameter of approximately $70 \mathrm{~nm}$ with a rough surface. In addition, the sizes of these nanoparticles were quite uniform. The high-resolution TEM image on the edge of a nanoparticle indicated that the distance between two neighboring planes was $0.269 \mathrm{~nm}$ at (220), which is in good agreement with the (220) plane of the spinel $\mathrm{CoFe}_{2} \mathrm{O}_{4}$, as shown in the inset of Figure 1b. Figure 1c shows a histogram of the distribution of the nanoparticles size with a Gaussian fit curve (solid line); the particle size ranged from 45 to $85 \mathrm{~nm}$, and the average particle size $\left(D_{\mathrm{SEM}}\right)$, defined as the size at the peak of the Gaussian-fitting 
curve, was $69.2 \mathrm{~nm}$. These results indicated that our $\mathrm{CoFe}_{2} \mathrm{O}_{4}$ nanoparticles were well dispersed and had a narrow size distribution.
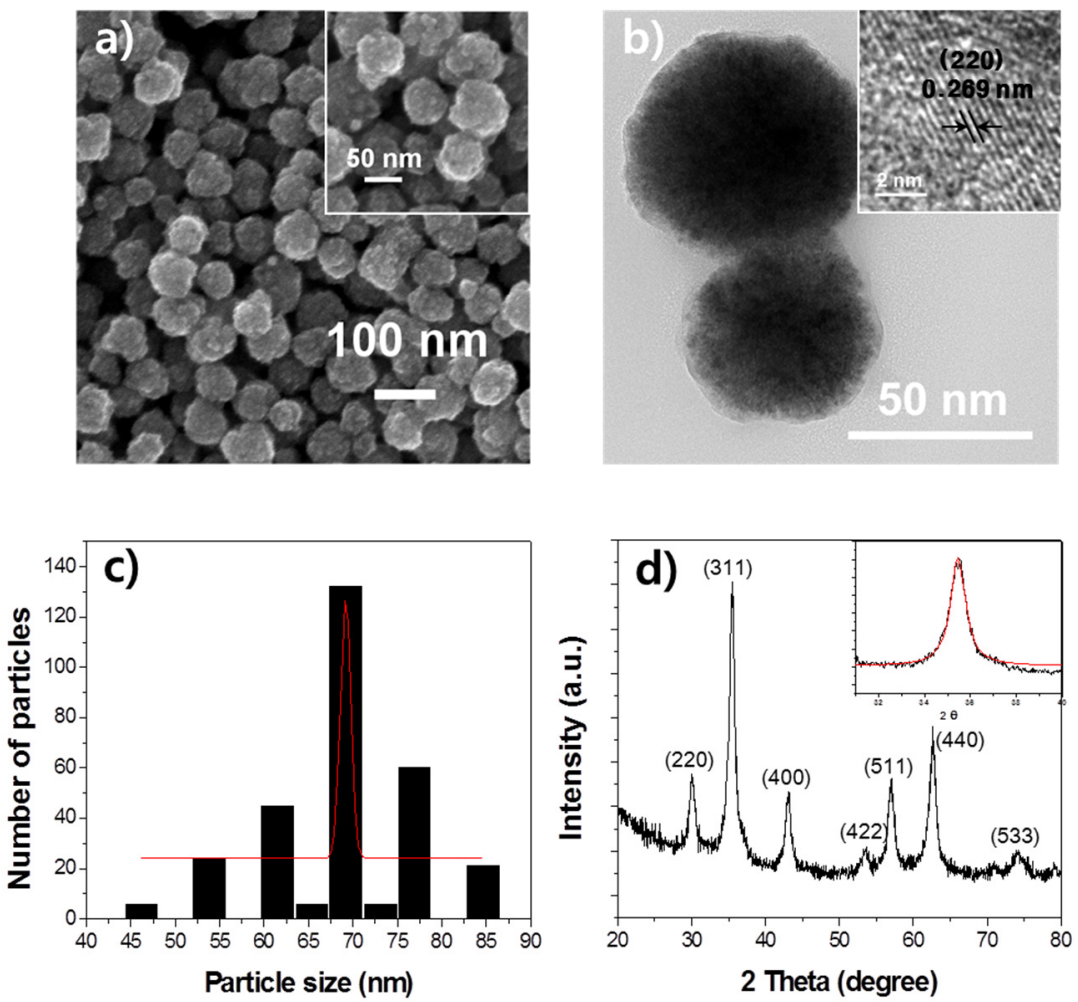

Figure 1. Morphology and crystal structure of the $\mathrm{CoFe}_{2} \mathrm{O}_{4}$ nanoparticle. (a) Field-emission scanning electron microscopy image and (b) transmission electron microscopy micrographs of the $\mathrm{CoFe}_{2} \mathrm{O}_{4}$ nanoparticle; (c) Histogram for the particle size distribution of the $\mathrm{CoFe}_{2} \mathrm{O}_{4}$ nanoparticles; (d) X-ray diffraction pattern of the $\mathrm{CoFe}_{2} \mathrm{O}_{4}$ nanoparticles.

The structure and phase purity of the nanoparticles were confirmed by analysis of the X-ray diffraction (XRD; PANalytical, $X^{\prime}$ Pert Pro MPD) patterns and the results are presented in Figure 1d. The diffraction peaks matched well with the characteristic peaks of the cubic spinel-type lattice of $\mathrm{CoFe}_{2} \mathrm{O}_{4}$, which in turn is well matched to the standard XRD pattern (JCPDS Card No. 22-1086). The peaks observed at $30.1^{\circ}, 35.5^{\circ}, 43.1^{\circ}, 53.6^{\circ}, 57.1^{\circ}, 62.7^{\circ}$, and $74.2^{\circ}$ can be assigned to the (220), (311), (400), (422), (511), (440), and (533) planes of spinel $\mathrm{CoFe}_{2} \mathrm{O}_{4}$, respectively. This result indicates that the obtained high-purity $\mathrm{CoFe}_{2} \mathrm{O}_{4}$ nanoparticles have good crystallinity. The average crystallite size of the $\mathrm{CoFe}_{2} \mathrm{O}_{4}$ nanograin was estimated to be approximately $9.25 \mathrm{~nm}$ via X-ray line broadening using Scherrer's equation.

The $\mathrm{CoFe}_{2} \mathrm{O}_{4}$ nanoparticles and $\mathrm{CoFe}_{2} \mathrm{O}_{4}$-HPs-FAs showed good magnetic properties. Figure 2a presents the room-temperature hysteresis loop as a function of the applied magnetic field, or the $\mathrm{M}$ versus $\mathrm{H}$ curve. The magnetization curves of both samples exhibited no hysteresis, and no coercivity was reached, even at the highest magnetic field applied. This indicates that both magnetic particles show superparamagnetic behavior. The $\mathrm{CoFe}_{2} \mathrm{O}_{4}$ nanoparticles showed a high-saturation magnetization value of $67.3 \mathrm{emu} / \mathrm{g}$, whereas the high-saturation value of the surface-modified $\mathrm{CoFe}_{2} \mathrm{O}_{4}$-HPs-FAs was lower at $39.7 \mathrm{emu} / \mathrm{g}$. The difference in the saturation values is attributed to the diamagnetic contribution of the diamagnetic organic molecules that are chemically bonded to the nanoparticle surface.

From the photoluminescence and photoluminescence excitation spectra shown in Figure $2 \mathrm{~b}$, the HP solution showed excitation peaks at 401 (Soret band), 500, 532, and $574 \mathrm{~nm}$ (Q band), and the $\mathrm{CoFe}_{2} \mathrm{O}_{4}$-HPs-FAs solution showed the same characteristic peaks. No significant shift in the 
excitation wavelength was observed in comparison to the dissolved $\mathrm{CoFe}_{2} \mathrm{O}_{4}$-HPs-FAs, suggesting that the HP molecules, as a PS, remained stable after conjugation to the nanoparticles. At the excitation wavelength of $400 \mathrm{~nm}$, the pure HP produced two strong emission peaks located at $631 \mathrm{~nm}$ and $696 \mathrm{~nm}$, respectively, and the $\mathrm{CoFe}_{2} \mathrm{O}_{4}$-HPs-FAs exhibited slightly blue-shifted peaks at $628 \mathrm{~nm}$ and $694 \mathrm{~nm}$. The blue-shifted emission peaks are attributed to the strong bonding between $\mathrm{HP}$ and the magnetic $\mathrm{CoFe}_{2} \mathrm{O}_{4}$ nanoparticles.

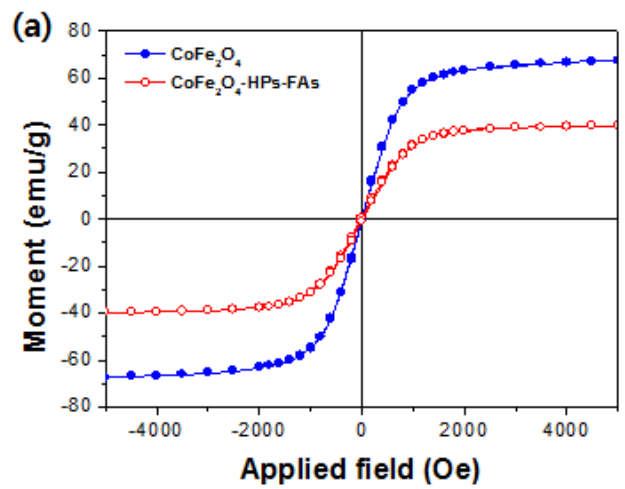

(c)

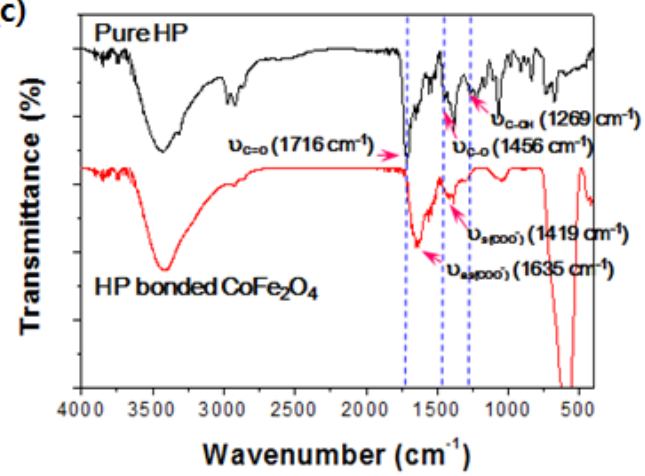

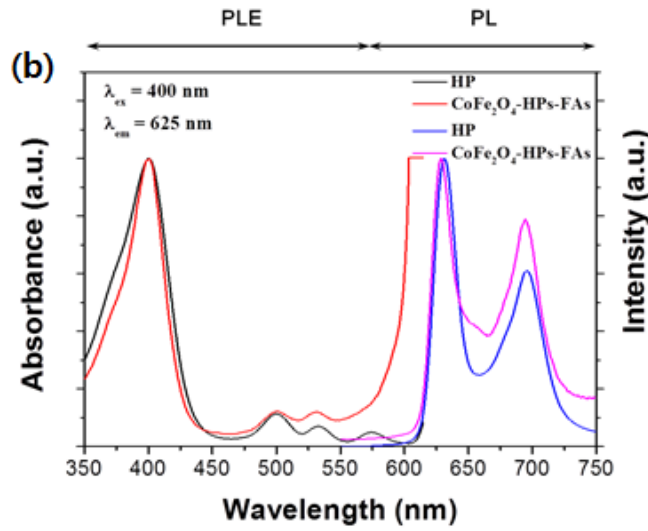

(d)

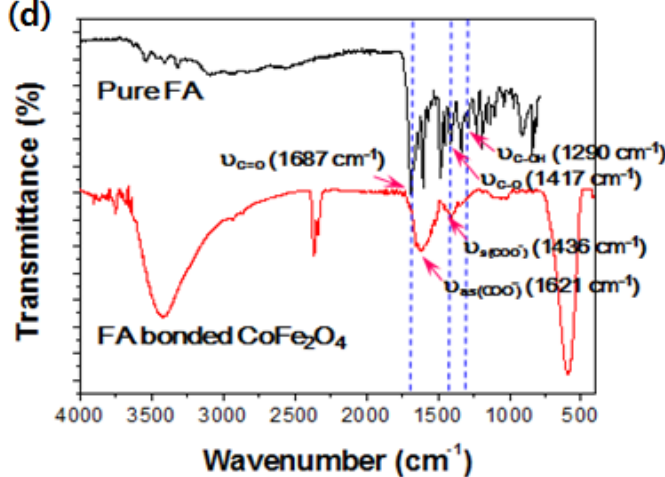

Figure 2. Photophysical and magnetic properties of multifunctional magnetic nanoparticles. (a) Room-temperature magnetic hysteresis loops of the $\mathrm{CoFe}_{2} \mathrm{O}_{4}$ nanoparticles and the $\mathrm{CoFe}_{2} \mathrm{O}_{4}$-HPs-FAs; (b) photoluminescence and photoluminescence excitation spectra of pure HP and $\mathrm{CoFe}_{2} \mathrm{O}_{4}$-HPs-FAs in THF; FT-IR spectra of (c) pure HP and HP bound with $\mathrm{CoFe}_{2} \mathrm{O}_{4}$ and of (d) pure FA and FA bonded with $\mathrm{CoFe}_{2} \mathrm{O}_{4}$.

To confirm the formation of the metal-organic complex, the Fourier Transform InfraRed (FT-IR) spectra of pure $\mathrm{HP}, \mathrm{HP}$-coated $\mathrm{CoFe}_{2} \mathrm{O}_{4}$, and $\mathrm{FA}$-coated $\mathrm{CoFe}_{2} \mathrm{O}_{4}$ nanoparticles were compared. As shown in Figure $2 \mathrm{c}, \mathrm{d}$, the absorption peaks were mainly detected in the fingerprint region. Before complex formation, the IR spectra of pure HP and pure FA exhibited a peak in the range of $1687-1716 \mathrm{~cm}^{-1}$, indicating the presence of a $\mathrm{C}=\mathrm{O}$ stretching band of the $-\mathrm{COOH}$ groups. In addition, coupled vibrations involving $\mathrm{C}-\mathrm{O}$ stretching and the $\mathrm{O}-\mathrm{H}$ deformation $\left(v_{\mathrm{C}-\mathrm{OH}}\right)$ were observed in the range of $1417-1456 \mathrm{~cm}^{-1}$ and $1269-1290 \mathrm{~cm}^{-1}$, respectively. These results indicate that the pure HP and FA molecules have protonated carboxyl groups (-COOH), as previously described [22]. After the carboxyl acid was converted to the complexes, the IR spectra of $\mathrm{HP}$-coated $\mathrm{CoFe}_{2} \mathrm{O}_{4}$ and FA-coated $\mathrm{CoFe}_{2} \mathrm{O}_{4}$ nanoparticles showed that the absorption bands of the protonated carboxyl groups significantly changed. Three absorption bands corresponding to the stretching vibrations of the $\mathrm{C}=\mathrm{O}$ group, $(\mathrm{C}-\mathrm{O})$, and $v_{\mathrm{C}-\mathrm{OH}}$ of the $-\mathrm{COOH}$ group at $1260-1720 \mathrm{~cm}^{-1}$ disappeared, whereas the bands assigned to asymmetric vibrations $v_{\text {as }}(\mathrm{COO})$, at $1621-1635 \mathrm{~cm}^{-1}$, and symmetric vibrations 
$v_{\mathrm{s}}(\mathrm{COO})$, at $1419-1436 \mathrm{~cm}^{-1}$, appeared. These spectral changes can also be caused by the formation of cation-carboxylate complexes owing to covalent chemical bonding, as described previously [22,23].

The loading capacity with HP molecules of the multifunctional $\mathrm{CoFe}_{2} \mathrm{O}_{4}$-HPs-FAs was determined by UV-Vis spectroscopy (Ultraviolet-visible spectroscopy). From the calculated results, when the $\mathrm{CoFe}_{2} \mathrm{O}_{4}$ nanoparticle weights varied at 1.56, 3.13, 6.25, 12.5, and $25 \mu \mathrm{g}$, the weights of the HP molecules bonded to the surfaces of the $\mathrm{CoFe}_{2} \mathrm{O}_{4}$ nanoparticles were $0.2,0.4,0.8,1.60$, and $3.22 \mu \mathrm{g}$, respectively. Similarly, the concentrations of the FA molecules bonded to the surfaces of the $\mathrm{CoFe}_{2} \mathrm{O}_{4}$ nanoparticles were $0.09,0.17,0.35,0.69$, and $1.38 \mu \mathrm{g}$ according to the weights of the $\mathrm{CoFe}_{2} \mathrm{O}_{4}$ nanoparticles of 1.56 , $3.13,6.25,12.5$, and $25 \mu \mathrm{g}$, respectively.

\subsection{Singlet Oxygen Generation}

In a PDT process, absorption of light by PSs eventually results in the generation of singlet oxygen and other ROS. Singlet oxygen is the major cytotoxic species leading to cell death through the so-called type II mechanism [24,25]. To evaluate the capability of ${ }^{1} \mathrm{O}_{2}$ generation of $\mathrm{CoFe}_{2} \mathrm{O}_{4}$-HPs-FAs, 1,3-diphenylisobenzofuran (DPBF) was employed as a probe molecule. Figure 3 shows the extensive bleaching of DPBF as a function of time (amplitude reduction of spectral features at $424 \mathrm{~nm}$ ) when incubated with $\mathrm{CoFe}_{2} \mathrm{O}_{4}$-HPs-FAs in THF and irradiated with a Xe lamp. Control experiments with only DPBF using the same excitation wavelength showed no bleaching. Therefore, the multifunctional magnetic nanoparticles could be a very important PDT reagent.

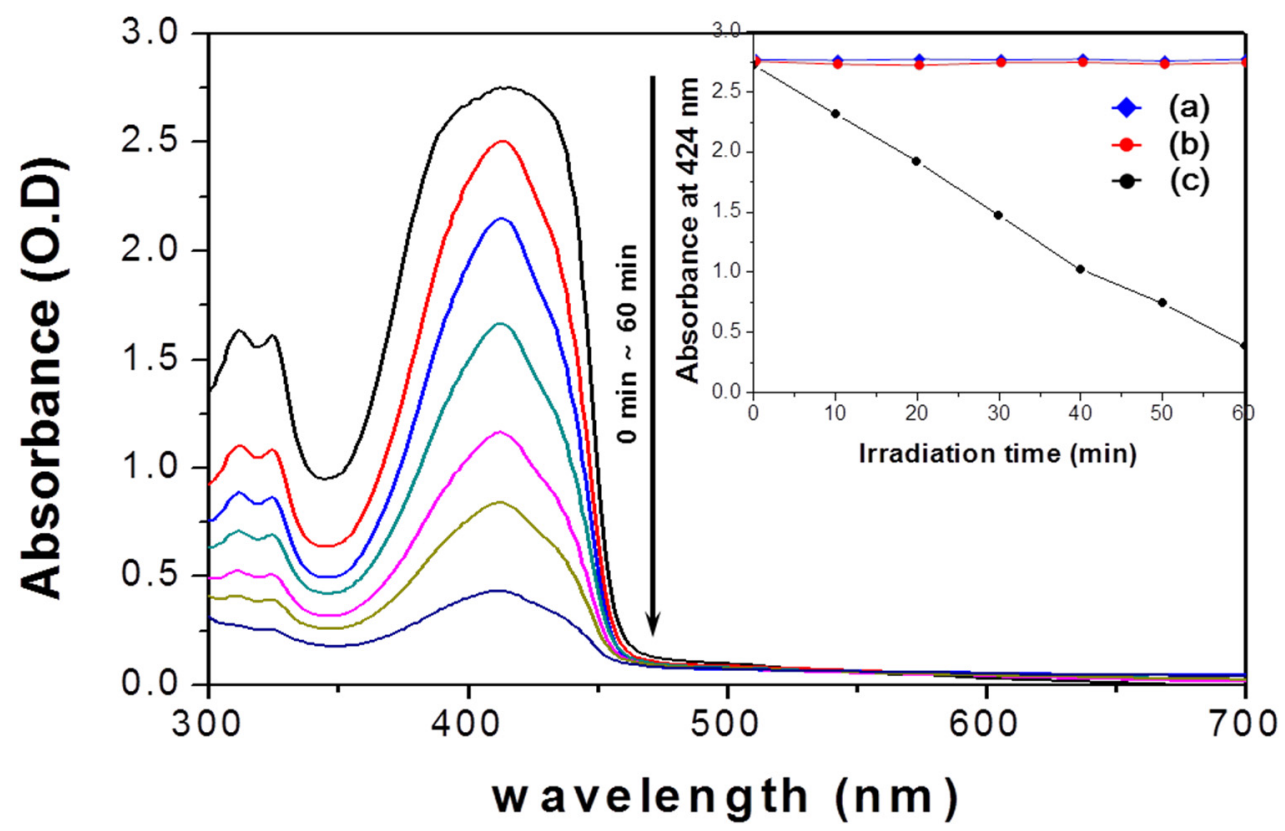

Figure 3. UV-Vis spectra of DPBF according to irradiation time in THF solution with the $\mathrm{CoFe}_{2} \mathrm{O}_{4}$-HPs-FAs under a Xe lamp. The inset presents the absorption (OD) of DPBF in THF at $424 \mathrm{~nm}$ as a function of irradiation time. (a) DPBF only plus light; (b) DPBF with the $\mathrm{CoFe}_{2} \mathrm{O}_{4}$-HPs-FAs without light; (c) DPBF with the $\mathrm{CoFe}_{2} \mathrm{O}_{4}$-HPs-FAs plus light.

\subsection{Biocompatibility of Multifunctional $\mathrm{CoFe}_{2} \mathrm{O}_{4}$-HPs-Fas}

As superparamagnetic $\mathrm{CoFe}_{2} \mathrm{O}_{4}$ nanoparticles are good $\mathrm{T}_{2}$-type (negative) contrast agents in MRI, and FA and HP are biocompatible cancer-targeting and therapeutic agents, the anti-cancer effect of $\mathrm{CoFe}_{2} \mathrm{O}_{4}$-HPs-FAs was investigated by evaluating the MR signal-enhancing property. With increasing concentrations of $\mathrm{CoFe}_{2} \mathrm{O}_{4}$-HPs-FAs in the cells, the MR signal was significantly enhanced (negative in brightness in the $\mathrm{T}_{2}$-weighted image) in vitro (Figure $4 \mathrm{a}$ ). These results indicate that the nanoparticles can generate high magnetic-field gradients near the surface of the 
$\mathrm{CoFe}_{2} \mathrm{O}_{4}$-HPs-FAs. Additionally, the relaxivity $\mathrm{r}_{2}\left(1 / \mathrm{T}_{2}\right)$ increases linearly under these conditions (Figure $4 \mathrm{~b}$ ), indicating that the $\mathrm{CoFe}_{2} \mathrm{O}_{4}$-HPs-FAs generated MRI contrasts on $\mathrm{T}_{2}$-weighted spin-echo sequences. Transverse relaxivity $r_{2}$ values were determined from the slope of the linear fit to the data points in $1 / \mathrm{T}_{2}$ vs. the $\mathrm{CoFe}_{2} \mathrm{O}_{4}$-HPs-FAs concentration plot. The $\mathrm{r}_{2}$ value obtained for $\mathrm{CoFe}_{2} \mathrm{O}_{4}$-HPs-FAs was $177.3 \mathrm{mM}^{-1} \mathrm{~s}^{-1}$. As shown in Figure $4 \mathrm{a}, \mathrm{b}$, the $\mathrm{T}_{2}$-weighted phantom images of the $\mathrm{CoFe}_{2} \mathrm{O}_{4}$-HPs-FAs exhibited a significant negative dose-dependent contrast enhancement, suggesting that these nanoparticles are promising for theragnostic purposes.

(a)

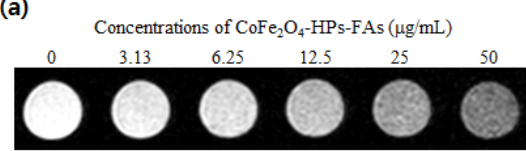

(b)

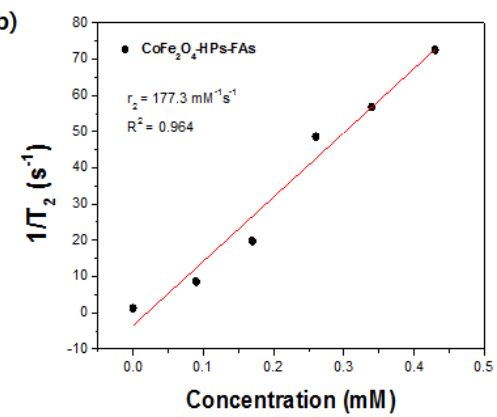

(c)

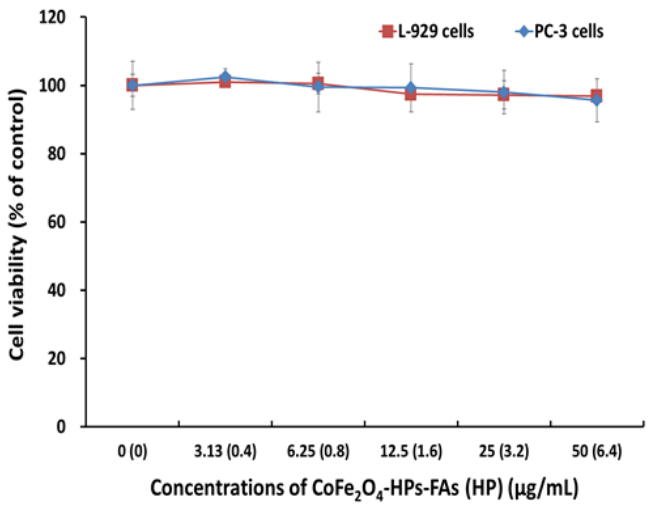

Figure 4. $\mathrm{T}_{2}$-weighted MR imaging and biocompatibility of $\mathrm{CoFe}_{2} \mathrm{O}_{4}$-HPs-FAs. (a) $\mathrm{T}_{2}$-weighted MR images of prostate cancer cells (PC-3 cells) treated with $\mathrm{CoFe}_{2} \mathrm{O}_{4}-\mathrm{HPs}-\mathrm{Fas}$; (b) Plot of $\mathrm{T}_{2}$ relaxation rate $\mathrm{r}_{2}\left(1 / \mathrm{T}_{2}\right)$ for $\mathrm{CoFe}_{2} \mathrm{O}_{4}$-HPs-Fas; (c) Cytotoxicity of $\mathrm{CoFe}_{2} \mathrm{O}_{4}$-HPs-FAs $(60 \mathrm{~nm})$ in fibroblasts (L-929 cells) and prostate cancer cells (PC-3 cells). Data are expressed as the mean \pm standard deviation $(n=6)$.

To evaluate the biocompatibility of the $\mathrm{CoFe}_{2} \mathrm{O}_{4}$-HPs-FAs, cytotoxicity tests were carried out with fibroblasts (L-929 cell) and prostate cancer cells (PC-3 cells) using a method recommended by the International Organization for Standardization (ISO 10993-5) [26]. As shown in Figure 4b, the viability of both cell types was not decreased when incubated with $\mathrm{CoFe}_{2} \mathrm{O}_{4}$-HPs-FAs as compared to the untreated control cells, and cell viabilities at each concentration of $\mathrm{CoFe}_{2} \mathrm{O}_{4}$-HPs-FAs were more than $95 \%$, indicating that the $\mathrm{CoFe}_{2} \mathrm{O}_{4}$-HPs-FAs have no cytotoxicity in L-929 and PC-3 cells. Collectively, these results demonstrate that $\mathrm{CoFe}_{2} \mathrm{O}_{4}$-HPs-FAs have good biocompatibility and can be used for clinical cancer therapy.

\subsection{Optimization of the Cellular Uptake and Light Irradiation Time of $\mathrm{CoFe}_{2} \mathrm{O}_{4}-\mathrm{HPs}-\mathrm{Fas}$}

Cellular uptake and the intracellular distribution of the $\mathrm{CoFe}_{2} \mathrm{O}_{4}$-HPs-FAs are the most important factors for their anticancer efficacy by PDT. Therefore, we carried out cell staining with the Prussian blue staining method and TEM analysis after incubating PC-3 prostate cancer cells with the $\mathrm{CoFe}_{2} \mathrm{O}_{4}$-HPs-FAs for 1, 2, and $4 \mathrm{~h}$ to confirm the optimal cellular uptake time and intracellular distribution. As shown in Figure 5a, incubation time had a substantial effect on the cellular uptake of the $\mathrm{CoFe}_{2} \mathrm{O}_{4}$-HPs-FAs. The number of $\mathrm{CoFe}_{2} \mathrm{O}_{4}$-HPs-FAs in the cells was proportional to the incubation time and the accumulated $\mathrm{CoFe}_{2} \mathrm{O}_{4}$-HPs-FAs in PC-3 cells appeared to be located in the cytosol. As shown in Figure 5b, the TEM images also clearly demonstrated that most of the $\mathrm{CoFe}_{2} \mathrm{O}_{4}$-HPs-FAs were located in the cytoplasm, and the number of $\mathrm{CoFe}_{2} \mathrm{O}_{4}$-HPs-FAs in the cytoplasm was also increased depending on the incubation time with cells.

To further evaluate the optimal cellular uptake time of the $\mathrm{CoFe}_{2} \mathrm{O}_{4}$-HPs-FAs in prostate cancer cells, the PC-3 cells were incubated with the $\mathrm{CoFe}_{2} \mathrm{O}_{4}$-HPs-FAs for 1, 2, and $4 \mathrm{~h}$, and each cell was irradiated with LED light at a dose of $18.36 \mathrm{~J} / \mathrm{cm}^{2}$ to confirm the anticancer activity of the 
$\mathrm{CoFe}_{2} \mathrm{O}_{4}$-HPs-FAs depending on the incubation time. As shown in Figure $5 \mathrm{c}$, the cell viabilities of PC-3 cells were decreased in a dose-dependent manner, regardless of the incubation time of the $\mathrm{CoFe}_{2} \mathrm{O}_{4}$-HPs-FAs with PC-3 cells. The cell viability with $1 \mathrm{~h}$ incubation was 100, 74, 53.6, 47.6, and $37.1 \%$ with increasing $\mathrm{CoFe}_{2} \mathrm{O}_{4}$-HPs-FA concentrations, respectively. However, the number of viable cells significantly decreased at 2 and $4 \mathrm{~h}$ incubation with increasing doses of the $\mathrm{CoFe}_{2} \mathrm{O}_{4}$-HPs-FAs, from $100,33.6,9.3,3.4$, and $0.4 \%$ for $2 \mathrm{~h}$ and from $100,34.6,9.6,8.9$, and $5.8 \%$ for $4 \mathrm{~h}$ compared to control levels. These results suggested that an increased incubation time-i.e., 2 and $4 \mathrm{~h}-$ resulted in significantly better photo-killing efficacy of $\mathrm{CoFe}_{2} \mathrm{O}_{4}$-HPs-FAs in PC-3 cells compared with a 1-h incubation time. Moreover, the photodynamic anticancer activity at $2 \mathrm{~h}$ of incubation was higher than that at $4 \mathrm{~h}$ of incubation at high concentrations (12.5 (1.60) and $25(3.22) \mu \mathrm{g} / \mathrm{mL}$ ) of $\mathrm{CoFe}_{2} \mathrm{O}_{4}-\mathrm{HPs}-\mathrm{FAs}$ (HPs). Specifically, the photo-killing efficacy of 12.5 (1.60) and 25 (3.22) $\mu \mathrm{g} / \mathrm{mL} \mathrm{CoFe} \mathrm{O}_{4}$-HPs-FAs (HPs) ranged from over $96 \%(p<0.005)$ to almost $100 \%$. These results confirmed a close correlation between cellular uptake time and anticancer efficacy by PDT, although there was no difference in the photo-killing efficacy between $2 \mathrm{~h}$ and $4 \mathrm{~h}$ of incubation. Therefore, we selected $2 \mathrm{~h}$ as the optimal incubation time for the subsequent photodynamic anticancer activity test of the $\mathrm{CoFe}_{2} \mathrm{O}_{4}$-HPs-FAs.

(a)

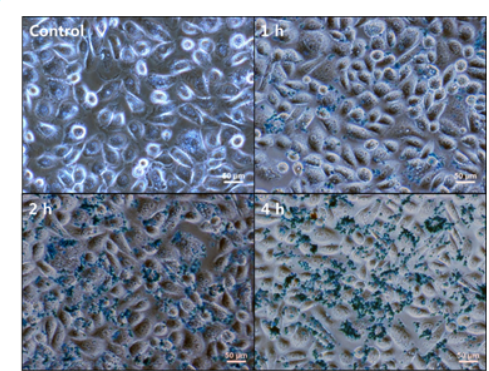

(c)

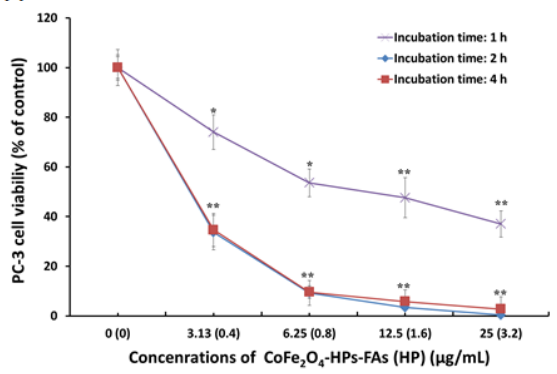

(b)

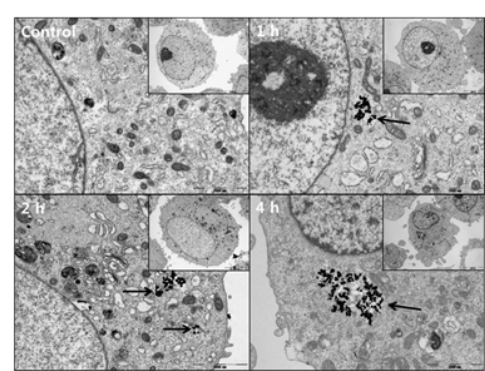

(d)

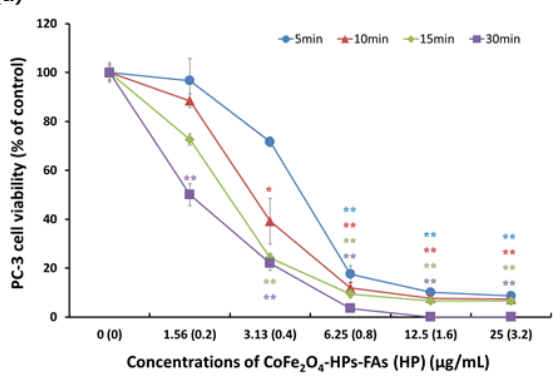

Figure 5. Cellular uptake, intracellular localization, and photodynamic anticancer activities of $\mathrm{CoFe}_{2} \mathrm{O}_{4}$-HPs-FAs in prostate cancer cells (PC-3 cells). (a) Microscopic and (b) transmission electron microscopic images of $\mathrm{CoFe}_{2} \mathrm{O}_{4}$-HPs-FAs in PC-3 cells to evaluate their cellular uptake and intracellular localization. PC-3 cells treated with $6.25(0.8) \mu \mathrm{g} / \mathrm{mL} \mathrm{CoFe}_{2} \mathrm{O}_{4}$-HPs-FAs (HPs) were incubated for 1,2 , and $4 \mathrm{~h}$ in the dark. The TEM images are magnified from a whole cell image (inset). Black arrows indicate the $\mathrm{CoFe}_{2} \mathrm{O}_{4}$-HPs-FAs. The scale bars represent $50 \mu \mathrm{m}$ and $2 \mu \mathrm{m}$; (c) Photodynamic anticancer activity of $\mathrm{CoFe}_{2} \mathrm{O}_{4}$-HPs-FAs according to the incubation time of $\mathrm{CoFe}_{2} \mathrm{O}_{4}$-HPs-FAs with prostate cancer cells (PC-3 cells); (d) Photodynamic anticancer activity of $\mathrm{CoFe}_{2} \mathrm{O}_{4}$-HPs-FAs according to the exposure dose of light emitting diode (LED) light to PC-3 cells. Data are expressed as the mean \pm standard deviation $(n=6)$ and were analyzed by Student's $t$-tests. Statistical significance was defined as $p<0.05\left({ }^{*} p<0.05,{ }^{* *} p<0.005\right.$ vs. control at the same time).

\subsection{Anticancer Activity of $\mathrm{CoFe}_{2} \mathrm{O}_{4}$-HPs-Fas}

To confirm the photodynamic anticancer activity according to the exposure dose of LED light exposed to PC-3 cells, the cells were incubated with various concentrations of the $\mathrm{CoFe}_{2} \mathrm{O}_{4}$-HPs-FAs and irradiated by LED light at doses of 3.06, 6.12, 9.18, and $18.36 \mathrm{~J} / \mathrm{cm}^{2}$ after incubation for $2 \mathrm{~h}$. The photo-killing efficacy was also quantified using the Cell Counting Kit-8 (CCK-8) method, as shown 
in Figure 5d. The photodynamic anticancer activities by LED irradiation were significantly increased under each dose, even at the lowest dose of $3.06 \mathrm{~J} / \mathrm{cm}^{2}$, and cell viabilities dramatically decreased with increased concentrations of the $\mathrm{CoFe}_{2} \mathrm{O}_{4}$-HPs-FAs. The photo-killing efficacies of the $\mathrm{CoFe}_{2} \mathrm{O}_{4}$ - $\mathrm{HPs}_{3}-\mathrm{FAs}$ were markedly increased in a dose-dependent manner. These results demonstrated a close correlation between exposure dose of light and dose of the $\mathrm{CoFe}_{2} \mathrm{O}_{4}-\mathrm{HPs}-\mathrm{FAs}$ on the photo-killing efficacy.

Finally, to confirm the anticancer mechanism by PDT in PC-3 cells, we conducted morphological analysis to evaluate the rate of apoptotic cell death induced by LED irradiation after incubation with the $\mathrm{CoFe}_{2} \mathrm{O}_{4}$-HPs-FAs for $2 \mathrm{~h}$ using an Annexin V-fluorescein isothiocyanate (FITC) apoptosis detection kit and Hoechst 33342 fluorescence dye. Annexin V is an intracellular protein that binds to phosphatidylserine. Phosphatidylserine is normally only found on the intracellular face of the plasma membrane in healthy cells, whereas during the early stage of apoptosis, membrane asymmetry is lost and phosphatidylserine translocates to an external site. Therefore, FITC-labeled Annexin V can be used to specifically target and identify apoptotic cells.

Figure 6 a shows the stained images of normal and apoptotic cells at $2 \mathrm{~h}$ post-irradiation. In the control (untreated), cells stained by Annexin V-FITC and propidium iodide (PI) were not detected, whereas the cells treated with the $\mathrm{CoFe}_{2} \mathrm{O}_{4}$-HPs-FAs were stained green by Annexin V-FITC and red by PI. Cells showing only green fluorescence indicated early-stage apoptotic cells for cell membrane translocation, whereas double-stained cells in green and red indicated late-stage apoptotic cells. The results demonstrated that LED irradiation after treatment of the $\mathrm{CoFe}_{2} \mathrm{O}_{4}$-HPs-FAs to cancer cells is mediated by the induction of cell death, and the majority of cell death was mediated via apoptosis.

(a)

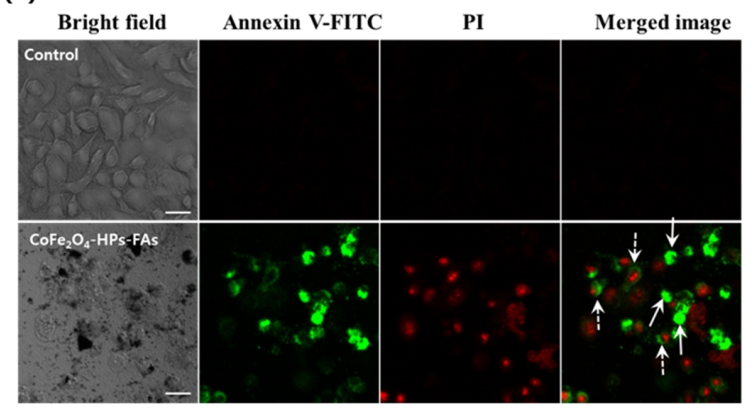

(b)

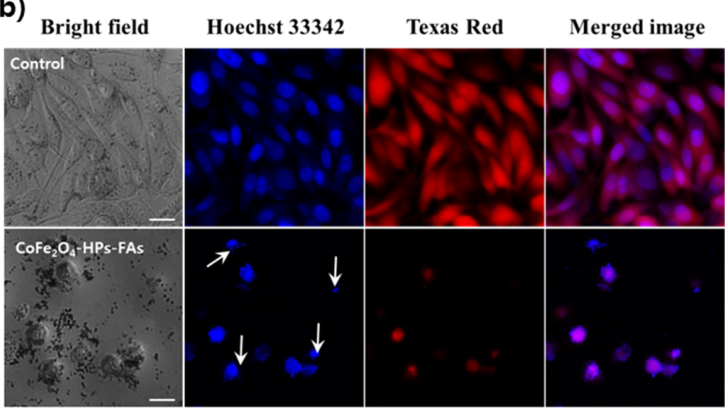

Figure 6. Confocal fluorescence images for cell membrane translocation and nuclear fragmentation in apoptotic PC-3 cells. (a) Confocal fluorescence images for cell membrane translocation stained with Annexin V-FITC (green) for the cell membrane and propidium iodide (PI, red) for the nucleus in PC-3 cells at $6 \mathrm{~h}$ post-irradiation. Cells stained green are apoptotic cells, and solid line and dashed arrows indicate early- and late-stage apoptotic cells, respectively; (b) Confocal fluorescence images for nuclear fragmentation (solid line arrows) stained with Hoechst 33342 (blue) for the nucleus and with Texas Red (red) for whole cells in PC-3 cells at $6 \mathrm{~h}$ post-irradiation. Apoptotic cell death was induced by LED irradiation at an irradiation dose of $18.36 \mathrm{~J} / \mathrm{cm}^{2}$ after treatment with $6.25(0.8) \mu \mathrm{g} / \mathrm{mL}$ $\mathrm{CoFe}_{2} \mathrm{O}_{4}$-HPs-FAs (HPs) for $2 \mathrm{~h}$. The scale bar represents $25 \mu \mathrm{m}$. 
Moreover, we evaluated the extent of nucleus fragmentation in PC-3 cells with Hoechst 33342 dye. As shown in Figure 6b, the cells irradiated with LED light after treatment of the $\mathrm{CoFe}_{2} \mathrm{O}_{4}$-HPs-FAs for $2 \mathrm{~h}$ were quickly condensed and some showed a granular nucleus body, which was not detected in the control cells.

These results are consistent with the results of photodynamic anticancer efficacy shown in Figure $5 c, d$, further indicating that the photodynamic anticancer effects may be induced via apoptosis.

\section{Materials and Methods}

\subsection{Synthesis of Multifunctional $\mathrm{CoFe}_{2} \mathrm{O}_{4}$-HPs-Fas}

The $\mathrm{CoFe}_{2} \mathrm{O}_{4}$ magnetic nanoparticles were prepared by applying a similar method as that described in the previous report [27]. In brief, $0.36 \mathrm{~g} \mathrm{FeCl}_{3} \cdot 6 \mathrm{H}_{2} \mathrm{O}, 0.11 \mathrm{~g} \mathrm{CoCl}_{2} \cdot 2 \mathrm{H}_{2} \mathrm{O}$, and $1.5 \mathrm{~g} \mathrm{NaOAc}$ were dissolved in ethylene glycol/diethylene glycol mixture solvent $(5: 15, v / v)$, and then this mixture was vigorously stirred for $30 \mathrm{~min}$. The solution was transferred to an $80-\mathrm{mL}$ Teflon-lined autoclave, which was sealed and maintained at $200{ }^{\circ} \mathrm{C}$ for $10 \mathrm{~h}$, and was then cooled to room temperature naturally. The black precipitation was collected by magnetic decantation, washed with deionized water and absolute alcohol several times, and then dried in a vacuum oven at $60^{\circ} \mathrm{C}$ for $12 \mathrm{~h}$.

To conjugate more PS molecules, the surfaces of the $\mathrm{CoFe}_{2} \mathrm{O}_{4}$ nanoparticles were treated with micro-dielectric barrier discharge plasma for $30 \mathrm{~min}$ according to a previously reported method [22].

The photo-functionality and targeting functionality on the $\mathrm{CoFe}_{2} \mathrm{O}_{4}$ nanoparticles were achieved using a wet chemical process similar to the method described in our previous report [28].

\subsection{Characterization of Multifunctional $\mathrm{CoFe}_{2} \mathrm{O}_{4}$-HPs-Fas}

Field-emission scanning electron microscopy (FE-SEM; SU-70, Hitachi, Tokyo, Japan) and transmission electron microscopy (TEM; JEM-2100F, JEOL, Tokyo, Japan) were applied to determine the size and surface morphology of the multifunctional sub-micron particles. The X-ray diffraction (XRD; $X^{\prime}$ Pert Pro MPD, PANalytical, Almelo, The Netherlands) pattern of the product was determined on a PANalytical Pert Pro MPD X-ray diffractometer with a $\mathrm{Cu} \mathrm{K \alpha}$ radiation source $(\lambda=0.15405 \mathrm{~nm})$ operated at $40 \mathrm{kV}$ and $150 \mathrm{~mA}$ in a $2 \theta$ range of $20-80^{\circ}$. A vibrating sample magnetometer (VSM; Lakeshore 7300, Lake Shore Cryotronics, Westerville, OH, USA) was utilized to measure the magnetization versus magnetic field loop at room temperature up to $10 \mathrm{kOe}$. Photoluminescence and photoluminescence excitation spectra were measured on a spectrophotometer (F-4500, Hitachi, Tokyo, JApan). Infrared (IR) spectra were obtained using a Fourier transform (FT)-IR spectrometer (Spectrum 100, Perkin-Elmer, Waltham, MA, USA). For IR measurements, samples were prepared in an agate mortar and then prepared in the form of pressed wafers (ca. $1 \%$ sample in $\mathrm{KBr}$ ).

\subsection{Detection of Singlet Oxygen}

Degradation of 1,3-diphenylisobenzofuran (DPBF) as a singlet oxygen quencher was applied to determine the release of singlet oxygen into the solution [29]. In the photochemical experiment, an aliquot of $3.0075 \mathrm{~mL}$ of tetrahydrofuran (THF) solution containing the $\mathrm{CoFe}_{2} \mathrm{O}_{4}-\mathrm{HPs}-\mathrm{FAs}$ and DPBF $\left(4.61 \times 10^{-8} \mathrm{M}\right)$ was introduced to a 1-cm quartz cell in the dark. The light source was a Xe lamp (150 W, Abet Technologies, Milford, MA, USA). A 480-nm glass cutoff filter was used to remove the ultraviolet (UV) light, which prevents direct photodegradation of DPBF. Photodegradation of DPBF was monitored by recording the optical density (OD) of the absorption peak at $424 \mathrm{~nm}$. At every $10 \mathrm{~min}$ of irradiation, the absorption spectra of the samples were monitored on a UV-Vis spectrophotometer.

\subsection{Magnetic Resonance Imaging (MRI) Analysis In Vitro}

All MRI experiments were performed on a 3.0-Tesla whole-body MRI scanner (Philips Achieva X-series, Amsterdam, The Netherlands) using a dedicated phased array receiver coil for high-resolution MRI as previously described [22]. In brief, PC-3 cells (a prostate cancer cell line) pre-cultured for 
$24 \mathrm{~h}$ were incubated with various concentrations $(0,3.13,6.25,12.5,25$, and $50 \mu \mathrm{g} / \mathrm{mL})$ of the $\mathrm{CoFe}_{2} \mathrm{O}_{4}$-HPs-FAs for $2 \mathrm{~h}$ in a 24 -well culture plate. The cells were then fixed with a $2 \%$ glutaraldehyde and paraformaldehyde solution and mixed with a $1.5 \%$ agar solution in $1.5-\mathrm{mL}$ micro-centrifuge tubes for MRI.

\subsection{Biocompatibility of Multifunctional $\mathrm{CoFe}_{2} \mathrm{O}_{4}$-HPs-Fas}

Cellular toxicity tests on fibroblasts (L-929 cells) and prostate cancer cells (PC-3 cells) were carried out to confirm the biocompatibility of the $\mathrm{CoFe}_{2} \mathrm{O}_{4}$-HPs-FAs, as previously described [22,30-32]. In brief, each cell type was plated in a 24-well plate at $2.0 \times 10^{5}$ cells $/ \mathrm{mL}$ for L-929 cells and at $1.0 \times 10^{5}$ cells $/ \mathrm{mL}$ for PC-3 cells, incubated at $37{ }^{\circ} \mathrm{C}$ in $5 \% \mathrm{CO}_{2}$ for $24 \mathrm{~h}$, treated with various concentrations (0 (0), $3.13(0.4), 6.25(0.8), 12.5(1.60), 25(3.22)$, and $50(6.44) \mu \mathrm{g} / \mathrm{mL})$ of $\mathrm{CoFe}_{2} \mathrm{O}_{4}$-HPs-FAs (HPs), and then incubated at $37{ }^{\circ} \mathrm{C}$ in $5 \% \mathrm{CO}_{2}$ for a further $24 \mathrm{~h}$ under dark conditions. After incubation, the cells were washed three times with phosphate-buffer saline (PBS) and their viabilities were determined using Cell Counting Kit-8 (CCK-8, Dojindo Laboratories, Kumamoto, Japan). The OD value of each well was measured at $450 \mathrm{~nm}$ with a microplate reader (Synergy ${ }^{\mathrm{TM}} \mathrm{HT}$, BioTek Instruments, Inc., Winooski, VT, USA) and the cell viabilities are presented as the survival percentage relative to the untreated control.

3.6. Optimization of the Cellular Uptake and Light Irradiation Time for Photodynamic Anticancer Activity of Multifunctional $\mathrm{CoFe}_{2} \mathrm{O}_{4}$-HPs-Fas

To confirm the optimal cellular uptake time of $\mathrm{CoFe}_{2} \mathrm{O}_{4}$-HPs-FAs into the cells, PC-3 cells were plated in a 24-well plate at $1.0 \times 10^{5}$ cells $/ \mathrm{mL}$ and incubated at $37{ }^{\circ} \mathrm{C}$ in $5 \% \mathrm{CO}_{2}$ for $24 \mathrm{~h}$. The cells were further incubated with different concentrations (0 (0), $3.13(0.4), 6.25(0.8), 12.5$ (1.60), and $25(3.22) \mu \mathrm{g} / \mathrm{mL}$ ) of $\mathrm{CoFe}_{2} \mathrm{O}_{4}$-HPs-FAs (HPs) for 1, 2, and $4 \mathrm{~h}$ under dark conditions. The cells were washed three times with PBS, the medium was refreshed, and the cells were irradiated by a general green light-emitting diode (LED) at $18.36 \mathrm{~J} / \mathrm{cm}^{2}$ as previously reported [22,23,30-32]. The LED had a wavelength range of $480-580 \mathrm{~nm}$, a maximum wavelength of $515 \mathrm{~nm}$, and a maximum dose of $18.36 \mathrm{~J} / \mathrm{cm}^{2}$. After irradiation, the cells were incubated for another $24 \mathrm{~h}$ and the following day, their viabilities were measured using the CCK-8 kit as described above.

To confirm the cellular uptake and intracellular localization of $\mathrm{CoFe}_{2} \mathrm{O}_{4}$-HPs-FAs in PC-3 cell with image analysis, two kinds of methods were adopted: Prussian blue staining for cellular uptake and TEM analysis for intracellular localization, as previously described [22]. In brief, PC-3 cells treated with $\mathrm{CoFe}_{2} \mathrm{O}_{4}$-HPs-FAs $(6.25 \mu \mathrm{g} / \mathrm{mL})$ were washed with PBS three times after incubating for 1, 2, and $4 \mathrm{~h}$, and fixed with ice-cold acetone for $10 \mathrm{~min}$ to stain the cells with Prussian blue staining reagents. The fixed cells were stained with a $2 \%$ potassium ferrocyanide II and $1 \mathrm{M}$ hydrochloric acid mixture (ratio 1:1) for $10 \mathrm{~min}$ at $37^{\circ} \mathrm{C}$ after washing with PBS, and subsequently counterstained with a $0.1 \%$ solution of Nuclear Fast Red in distilled water with 5\% aluminum sulfate for 1 min after washing again with PBS. Finally, the stained cells were observed with an inverted microscope (Eclipse Ti, Nikon, Instruments, Inc., New York, NY, USA) after washing with distilled water. To evaluate the intracellular localization of $\mathrm{CoFe}_{2} \mathrm{O}_{4}$-HPs-FAs in prostate cancer cells, PC-3 cells treated with $\mathrm{CoFe}_{2} \mathrm{O}_{4}$-HPs-FAs $(6.25 \mu \mathrm{g} / \mathrm{mL})$ for 1,2 , and $4 \mathrm{~h}$ were washed with PBS three times and fixed with $2.5 \%$ glutaraldehyde and $4 \%$ formaldehyde for $4 \mathrm{~h}$ at $4{ }^{\circ} \mathrm{C}$. Fixed cells were washed with PBS twice and treated with $2 \%$ osmium tetroxide for $2 \mathrm{~h}$ at $4{ }^{\circ} \mathrm{C}$. The fixed cells were washed again with PBS and dehydrated with increasing concentrations of ethanol and embedded in araldite. The fixed PC-3 cells were then observed with TEM (JEM-1011, JEOL, Tokyo, Japan).

To evaluate the appropriate irradiation energy with green LED for targeting the cancer cells, PC-3 cells were plated in a 24-well plate and incubated for $24 \mathrm{~h}$ as described above. After incubation, the cells were incubated with different concentrations $(0(0), 1.56(0.2), 3.13(0.4), 6.25(0.8), 12.5(1.60)$, and $25(3.22) \mu \mathrm{g} / \mathrm{mL}$ ) of $\mathrm{CoFe}_{2} \mathrm{O}_{4}$-HPs-FAs (HPs) for $2 \mathrm{~h}$ and further incubated for $24 \mathrm{~h}$ after irradiation 
at doses of $3.06,6.12,9.18$, and $18.36 \mathrm{~J} / \mathrm{cm}^{2}$. The following day, the cell viabilities were measured using the CCK-8 kit as described above.

\subsection{Morphological Analysis of Apoptotic Cell Death in Prostate Cancer Cells}

To confirm the cell death after LED irradiation, the cell membranes and nuclei were stained with an EzWay ${ }^{\mathrm{TM}}$ Annexin V-FITC apoptosis detection kit (K29100, Komabiotech Inc., Seoul, Korea) and Texas Red C2-maleimide dye. The cell images were taken by a laser scanning microscope (LSM 700, Carl Zeiss, Oberkochen, Germany) with fluorescence optics (excitation at $488 \mathrm{~nm}$ for FITC, $530 \mathrm{~nm}$ for PI, $595 \mathrm{~nm}$ for Texas Red C2-maleimide, and $352 \mathrm{~nm}$ for Hoechst 33342; emission at $518 \mathrm{~nm}$ for FITC, $615 \mathrm{~nm}$ for Texas Red C2-maleimide, and $620 \mathrm{~nm}$ for PI) as previously described [22,23].

\subsection{Statistical Analysis}

All quantitative data $(n=6)$ are expressed as the means \pm standard deviation, and statistical comparisons were evaluated with a Student's $t$-test. Significant differences were indicated by $p<0.05$.

\section{Conclusions}

In the present study, we synthesized novel FA- and HP-conjugated multifunctional magnetic nanoparticles $\left(\mathrm{CoFe}_{2} \mathrm{O}_{4}\right.$-HPs-FAs), which were characterized as an effective anticancer reagent for PDT, and demonstrated the dependency of the photodynamic anticancer activities on the incubation time and the exposure dose of LED light in prostate cancer cells (PC-3 cells). These results indicate that the same fluence at different exposure doses results in dissimilar levels of anticancer activities on PC-3 cancer cells as well as in ROS formation. In addition, the increase of the fluence showed an improvement for cell photo-inactivation.

Acknowledgments: This work was supported financially by the National Research Foundation of Korea (NRF, \#2015M3A9E2066855 and \#2015M3A9E2066856) grant funded by the Korean government (MSIP) and by the Research Grant from Kwangwoon University in 2017.

Author Contributions: The manuscript was written through contribution of all authors. All authors have given approval to the final version of the manuscript. K.-H.C., K.C.N., and U.-H.K. contributed equally to this work.

Conflicts of Interest: The authors declare that there are no conflicts of interest regarding the publication of this paper.

\section{References}

1. Xie, J.; Pan, X.; Wang, M.; Yao, L.; Liang, X.; Ma, J.; Fei, Y.; Wang, P.-N.; Mi, L. Targeting and photodynamic killing of cancer cell by nitrogen-doped titanium dioxide coupled with folic acid. Nanomaterials 2016, 6, 113. [CrossRef] [PubMed]

2. Dougherty, T.J.; Gomer, C.J.; Henderson, B.W.; Jori, G.; Kessel, D.; Korbelik, M.; Moan, J.; Peng, Q. Photodynamic therapy. J. Natl. Cancer Inst. 1998, 90, 889-905. [CrossRef] [PubMed]

3. Chatterjee, D.K.; Fong, L.S.; Zhang, Y. Nanoparticles in photodynamic therapy: An emerging paradigm. Adv. Drug Deliv. Rev. 2008, 60, 1627-1637. [CrossRef] [PubMed]

4. Avula, U.M.; Kim, G.; Lee, Y.E.; Morady, F.; Kopelman, R.; Kalifa, J. Cell-specific nanoplatform-enabled photodynamic therapy for cardiac cells. Heart Rhythm 2012, 9, 1504-1509. [CrossRef] [PubMed]

5. Sibata, C.H.; Colussi, V.C.; Oleinick, N.L.; Kinsella, T.J. Photodynamic therapy: A new concept in medical treatment. Braz. J. Med. Biol. Res. 2000, 33, 869-880. [CrossRef] [PubMed]

6. Konopka, K.; Goslinski, T. Photodynamic therapy in dentistry. J. Dent. Res. 2007, 86, 694-707. [CrossRef] [PubMed]

7. Gursoy, H.; Ozcakir-Tomruk, C.; Tanalp, J.; Yilmaz, S. Photodynamic therapy in dentistry: A literature review. Clin. Oral Investig. 2013, 17, 1113-1125. [CrossRef] [PubMed] 
8. Mroz, P.; Bhaumik, J.; Dogutan, D.K.; Aly, Z.; Kamal, Z.; Khalid, L.; Kee, H.L.; Bocian, D.F.; Holten, D.; Lindsey, J.S.; et al. Imidazole metalloporphyrins as photosensitizers for photodynamic therapy: Role of molecular charge, central metal and hydroxyl radical production. Cancer Lett. 2009, 282, 63-76. [CrossRef] [PubMed]

9. Vrouenraets, M.B.; Visser, G.W.; Snow, G.B.; van Dongen, G.A. Basic principles, applications in oncology and improved selectivity of photodynamic therapy. Anticancer Res. 2003, 23, 505-522. [PubMed]

10. Konan, Y.N.; Gurny, R.; Allémann, E. State of the art in the delivery of photosensitizers for photodynamic therapy. J. Photochem. Photobiol. B Biol. 2002, 66, 89-106. [CrossRef]

11. Vivero-Escoto, J.L.; Elnagheeb, M. Mesoporous silica nanoparticles loaded with cisplatin and phthalocyanine for combination chemotherapy and photodynamic therapy in vitro. Nanomaterials 2015, 5, 2302-2316. [CrossRef] [PubMed]

12. Hah, H.J.; Kim, G.; Lee, Y.E.; Orringer, D.A.; Sagher, O.; Philbert, M.A.; Kopelman, R. Methylene blue-conjugated hydrogel nanoparticles and tumor-cell targeted photodynamic therapy. Macromol. Biosci. 2011, 11, 90-99. [CrossRef] [PubMed]

13. Lin, J.; Wang, S.; Huang, P.; Wang, Z.; Chen, S.; Niu, G.; Li, W.; He, J.; Cui, D.; Lu, G.; et al. Photosensitizer-loaded gold vesicles with strong plasmonic coupling effect for imaging-guided photothermal/photodynamic therapy. ACS Nano 2013, 7, 5320-5329. [CrossRef] [PubMed]

14. Simon, T.; Boca-Farcau, S.; Gabudean, A.M.; Baldeck, P.; Astilean, S. LED-activated Methylene blue-loaded pluronic-nanogold hybrids for in vitro photodynamic therapy. J. Biophotonics 2013, 6, 950-959. [CrossRef] [PubMed]

15. Yan, F.; Zhang, Y.; Kim, K.S.; Yuan, H.K.; Vo-Dinh, T. Cellular uptake and photodynamic activity of protein nanocages containing Methylene blue photosensitizing drug. Photochem. Photobiol. 2010, 86, 662-666. [CrossRef] [PubMed]

16. Wilson, B.C.; Patterson, M.S. The physics, biophysics and technology of photodynamic therapy. Phys. Med. Biol. 2008, 53, R61-R109. [CrossRef] [PubMed]

17. Huang, X.; Tian, X.J.; Yang, W.L.; Ehrenberg, B.; Chen, J.Y. The conjugates of gold nanorods and chlorin E6 for enhancing the fluorescence detection and photodynamic therapy of cancers. Phys. Chem. Chem. Phys. 2013, 15, 15727-15733. [CrossRef] [PubMed]

18. Chen, C.L.; Kuo, L.R.; Chang, C.L.; Hwu, Y.K.; Huang, C.K.; Lee, S.Y.; Chen, K.; Sin, S.J.; Huang, J.D.; Chen, Y.Y. In situ real-time investigation of cancer cell photothermolysis mediated by excited gold nanorod surface plasmons. Biomaterials 2010, 31, 4104-4112. [CrossRef] [PubMed]

19. Zhao, Z.; Shi, S.; Huang, Y.; Tang, S.; Chen, X. Simultaneous photodynamic and photothermal therapy using photosensitizer functionalized Pd nanosheets by single continuous wave laser. ACS Appl. Mater. Interfaces 2014, 6, 8878-8885. [CrossRef] [PubMed]

20. Vankayala, R.; Lin, C.C.; Kalluru, P.; Chiang, C.S.; Hwang, K.C. Gold nanoshells-mediated bimodal photodynamic and photothermal cancer treatment using ultra-low doses of near infra-red light. Biomaterials 2014, 35, 5527-5538. [CrossRef] [PubMed]

21. Song, X.; Liang, C.; Gong, H.; Chen, Q.; Wang, C.; Liu, Z. Photosensitizer-conjugated albumin-polypyrrole nanoparticles for imaging-guided in vivo photodynamic/photothermal therapy. Small 2015, 11, 3932-3941. [CrossRef] [PubMed]

22. Park, B.J.; Choi, K.H.; Nam, K.C.; Ali, A.; Min, J.E.; Son, H.; Uhm, H.S.; Kim, H.J.; Jung, J.S.; Choi, E.H. Photodynamic anticancer activities of multifunctional cobalt ferrite nanoparticles in various cancer cells. J. Biomed. Nanotechnol. 2015, 11, 226-235. [CrossRef] [PubMed]

23. Choi, K.H.; Nam, K.C.; Malkinski, L.; Choi, E.H.; Jung, J.S.; Park, B.J. Size-dependent photodynamic anticancer activity of biocompatible multifunctional magnetic submicron particles in prostate cancer cells. Molecules 2016, 21, 1187. [CrossRef] [PubMed]

24. Castano, A.P.; Mroz, P.; Hamblin, M.R. Photodynamic therapy and anti-tumour immunity. Nat. Rev. Cancer 2006, 6, 535-545. [CrossRef] [PubMed]

25. Collins, H.A.; Khurana, M.; Moriyama, E.H. Blood-vessel closure using photosensitizers engineered for two-photon excitation. Nat. Photonics 2008, 2, 420-424. [CrossRef]

26. International Organization for Standardization (ISO). International Standard ISO 10993-5:2009, Biological Evaluation of Medical Devices-Part 5: Tests for In Vitro Cytotoxicity; International Organization for Standardization: Geneva, Switzerland. 
27. Choi, K.H.; Choi, E.W.; Min, J.E.; Son, H.; Uhm, H.S.; Choi, E.H.; Park, B.J.; Jung, J.S. Comparison study on photodynamic anticancer activity of multifunctional magnetic particles by formation of cations. IEEE Trans. Magn. 2014, 50, 5200704. [CrossRef]

28. Choi, K.H.; Lee, H.J.; Park, B.J.; Wang, K.K.; Shin, E.P.; Park, J.C.; Kim, Y.K.; Oh, M.K.; Kim, Y.R. Photosensitizer and vancomycin-conjugated novel multifunctional magnetic particles as photoinactivation agents for selective killing of pathogenic bacteria. Chem. Commun. 2012, 48, 4591-4593. [CrossRef] [PubMed]

29. Choi, K.H.; Wang, K.K.; Shin, E.P.; Oh, S.L.; Jung, J.S.; Kim, H.K.; Kim, Y.R. Water-soluble magnetic nanoparticles functionalized with photosensitizer for photocatalytic application. J. Phys. Chem. C 2011, 115, 3212-3219. [CrossRef]

30. Choi, K.H.; Nam, K.C.; Kim, H.J.; Min, J.; Uhm, H.S.; Choi, E.H.; Park, B.J. Synthesis and characterization of photo-functional magnetic nanoparticles $\left(\mathrm{Fe}_{3} \mathrm{O}_{4} @ \mathrm{HP}\right)$ for applications in photodynamic cancer therapy. J. Korean Phys. Soc. 2014, 65, 1658-1662. [CrossRef]

31. Park, B.J.; Choi, K.H.; Nam, K.C.; Min, J.; Lee, K.D.; Uhm, H.S.; Choi, E.H.; Kim, H.J.; Jung, J.S. Photodynamic anticancer activity of $\mathrm{CoFe}_{2} \mathrm{O}_{4}$ nanoparticles conjugated with hematoporphyrin. J. Nanosci. Nanotechnol. 2015, 15, 7900-7906. [CrossRef] [PubMed]

32. Nam, K.C.; Choi, K.H.; Lee, K.D.; Kim, J.H.; Jung, J.S.; Park, B.J. Particle size dependent photodynamic anticancer activity of hematophorphyrin-conjugated $\mathrm{Fe}_{3} \mathrm{O}_{4}$ particles. J. Nanomater. 2016, 2016, 1278393. [CrossRef]

(C) 2017 by the authors. Licensee MDPI, Basel, Switzerland. This article is an open access article distributed under the terms and conditions of the Creative Commons Attribution (CC BY) license (http://creativecommons.org/licenses/by/4.0/). 